\title{
Intercultural Cybercommunication: Negotiation of Representations of Languages and Cultures in Multilingual Chatrooms
}

\author{
Mário Rui Domingues Ferreira da Cruz \\ Universidade de Aveiro, Aveiro, Portugal
}

The creation of a global citizen, who is able to participate in the public discourse, depends on the development of plurilingual and intercultural communicative competences, supported by a physical and online mobility. The purpose of this paper is to show how the integration of chats within the teaching/learning process of English and Portuguese as foreign languages offers possibilities of developing these competences in university students from Portugal and the USA. The study will focus on the processes of negotiation of representations of languages and cultures in order to analyse the intercultural communicative and plurilingual competences in action. The data are composed of sequences of two multilingual chat sessions which occurred during a school year. In the analysis of the Internet discourse, it will be possible to observe how chatters became competent intercultural cybercommunicators through negotiating representations of languages as learning, affective and cultural objects.

doi:10.1080/17447140802153642

\section{Introduction}

Nowadays it is important to be able to participate in the global discourse and to become a global citizen able to move across countries all over the world and use different languages to establish communication. On the one hand, this can be achieved by programmes, such as Comenius, Erasmus, Erasmus-mundus, VULCANUS ${ }^{1}$ or even SMILE (Student Mobility in Latin America, Caribbean and Europe), which are available to any university students willing to study (and even work) in other countries across the globe; on the other hand, the development of the Information and Communication Technologies (ICT) has increased to such an extent that it has made contact with world diversity easier. In addition, this type of communication entails different languages and cultures, making its users effective members of diversity and pluralism that circulate on the Internet. This 'online mobility' (Cruz \& Melo, 2004) can therefore be understood as the possibility to travel through the virtual world of the Internet, by accessing online communicative tools and, consequently, to overcome possible frontiers, which are imposed by the lack of knowledge of codes and languages.

Consequently, it is imperative to think about forms to enhance the use of these technologies, particularly the synchronous online communication, which may give way to a great qualitative change in pedagogical practices, providing 
what Tella (1995) calls 'networking instead of isolation'. In this way, by using this type of communication there are more opportunities to contact with multiple European languages and cultures, developing the competences of an 'intercultural cybercommunicator' (Cruz, 2005), whose profile we will try to define in this paper.

Moreover, we will try to show the potentialities of this type of interaction in the development of 'online mobility', namely the appearance and the negotiation of representations of languages and cultures in an online multilingual interaction. In fact, we think that these representations may have significant effects on the attitudes of chatters towards some languages and cultures at the expense of others. We will observe how these representations appear in chat discourse and analyse how they are negotiated.

\section{Multilingualism and Mobility}

Some countries all over the world have made language policies a priority in order to create a common communicative sphere based on the respect for diversity. This is the case of most countries in the European Union but also of countries such as the USA or Canada, which have strong immigrant communities and have fostered bilingual education approaches. In the past years some actions have been taken towards language policies, namely: on the one hand, regulatory laws towards a defence of multilingualism (including minority languages); on the other hand, the application of those laws in terms of mobility programmes (such as Socrates, Comenius, VULCANUS, SMILE, etc.) and international research teams, which prepare students to move across the world without any language barriers.

By promoting multilingualism, several concepts are being taken seriously by a lot of countries, including plurilingual competence (PC), which has become a key concept. The latter can be defined as 'the ability to use languages for the purposes of communication and to take part in intercultural interaction, where a person, viewed as a social agent, has proficiency in several languages and experience of several cultures' (Council of Europe, 2003: 168). In relation to this specific competence, Byram (2000: 297) has defined intercultural communicative competence (ICC) as the 'ability to interact effectively with people from cultures that we recognize as being different from our own. Cultures simultaneously share and differ in certain aspects, e.g. beliefs, habits and values. (...) Interacting effectively across cultures means accomplishing a negotiation between people based on both culture-specific and culture-general features that are on the whole respectful of and favourable to each.' In his model of competence (see Table 1 for details), two new dimensions unseen in the previous concept - identitary and political dimensions - are brought into the analysis, giving a more individualised, human, global and complex insight into what the plurilingual speaker may be.

This intercultural speaker can be defined as a negotiator 'between his own cultural, social and political identifications and representations with those of the other, that is, he has to be critical' (cf. Byram, 2000: 297). This means he/she is a person who is able to move between languages and cultures, i.e. who can manage his/her plurilingual and pluricultural competence, within geographic 
Table 1 Domains of intercultural communicative competence

\begin{tabular}{||l|l|l||}
\hline & $\begin{array}{l}\text { SKILLS interpret and } \\
\text { relate (savoir comprendre) }\end{array}$ & \\
\hline $\begin{array}{l}\text { KNOWLEDGE of self } \\
\text { and other; of interaction: } \\
\text { individual and societal } \\
\text { (les savoirs) }\end{array}$ & $\begin{array}{l}\text { EDUCATION political } \\
\text { education; critical } \\
\text { cultural awareness } \\
\text { (savoir s'engager) }\end{array}$ & $\begin{array}{l}\text { ATTITUDES } \\
\text { relativising self valuing } \\
\text { others } \\
\text { (savoir être) }\end{array}$ \\
\hline & $\begin{array}{l}\text { SKILLS discover and/ } \\
\text { or interact (savoir } \\
\text { apprendre/faire) }\end{array}$ & \\
\hline
\end{tabular}

Source: Byram (1997).

or/and online spaces, establishing 'identitary passerelles' (showing others who he/she is on online 'catwalks') and being capable of co-creating 'happy communicative moments' (Auchlin, 1995). At the same time he or she knows that differences and similarities are cultural constructions which may improve personal and interpersonal development.

Shi-xu and Wilson (2001) talk about a 'cross-cultural competence' which 'normally refers to knowledge about and skills in the cultural Other's language and culture as well as the working language and associated culture. They are the key to success (...).' The more knowledge and skills one has about the Other's language and culture, the less intercultural communication breakdowns will occur.

Now let us focus on the following concepts: 'mobility' and 'intercultural communicator' within a particular context - the rise of Internet access and its communicative tools. In this way, we will be able to talk about 'online mobility' and 'intercultural cybercommunicator' as two concepts related to the intercultural and multilingual Internet environment.

\section{Online Mobility and Intercultural Cybercommunication}

The development of ICT has allowed its users to become effective members of the diversity that one can find in cyberspace. In fact, ICT has made the emergence of an online mobility in a cybernetic world possible. Therefore, one can say that its users are capable of travelling within a virtual world by technological means, breaking through the possible barriers imposed by the absence of knowledge related to the use of codes and languages.

In fact, one must say that this concept of 'online mobility' is linked to another concept: 'electronic literacy' (Warschauer, 1999). The latter is related to a 'network culture' (Warschauer, 1999) and to the knowledge that the existence of that culture implies. Electronic literacy includes attitudes, behaviours and knowledge, which are used and updated within ICT usage, namely while using IRC, e-mail, newsgroups and chatrooms, among others. Furthermore, one can say that this electronic literacy embodies diverse literacies, which is a concept used by The New London Group (2000) and can be defined as: on the one hand, the increasing cultural and linguistic diversity and its negotiation 
which occurs within different communities; on the other hand, the influence of a multimodal negotiation with the Other.

To sum up, one could consider 'online mobility' as the ability both to recognise and use technological resources and to enrich knowledge which can indeed increase its usage. In our opinion, online mobility could be developed through correct usage of the technological means (the computer itself, both software and hardware), the communicative instruments (online communication tools), the linguistic and communicative codes (smiles, foreign languages, acronyms, etc.), the knowledge one has of enunciation, discursive and pragmatic characteristics and, last but not least, the mobilisation of social and affective predispositions towards the encounter itself.

Synchronous communication plays an important role in virtual intercultural communication. Chats are a sort of conversation which is written, occurs in real time and offers the possibility of having many people interacting at the same time (cf. Draelants, 2001). Morala (2001) argues that this type of communication is very colloquial and its context is very similar to a bar because chatters can ignore interlocutors, enter and leave the conversation whenever they feel like it or even maintain multiple dialogues at the same time. According to Portine (2001: 183), chats are 'espaces sociaux d'expression' [social spaces of expression] which allow the participation of a variable number of interlocutors of different geographic and temporal locations.

At the same time this type of communication is fragmentary, which results in the continuous reconstruction of the communication by the interlocutors. According to Araújo e Sá and Melo (2003a: 99), this has to do with the 'rapidez $y$ la brevedad de las interacciones y las aparentes incoherencias a nivel de organización textual' [promptness and briefness of the interactions and the apparent incoherencies in the text organisation].

In order to make the interaction a lot easier, expressive resources can be used, such as the smileys which 'sacan la lengua, fruncen el ceño, abren la boca sorprendidos, besan, ríen a carcajadas, sueñan, cierran ambos ojos y una multitud de gestos que codifican la gestualidad de la conversación oral por media de un ejercicio de abstracción y expresión creativo' [show their tongues, open their mouths with surprise, frown their eyebrows, kiss, laugh out loud, dream, close both eyes and perform many other gestures which represent the ones used in oral conversation as a creative and activity] (Planells, 2001).

There are many smileys one can use, but only three or four of them are used on a regular basis, such as:

$$
\text { smiling }
$$

winking

sad

kissing

(o) crying

Considering that the use of virtual synchronous communication is one of the main characteristics of a 'perfect' intercultural cybercommunicator (Cruz, 2006), let us now analyse other features that make part of his/her profile. This 
is the intercultural communicator who does not confine his/her learning to the classroom walls. In fact, this is the one who is capable of developing his/her own ICC using the virtual world. As Byram (1997: 64) states in the following extract ' $(. .$.$) the limitations of the classroom can be overcome to some degree$ by learning beyond the classroom walls, where the teacher still has a role. As FLT is increasingly seen as linked with education for mobility, there is a corresponding interest in visits, exchanges and other forms of contact, both real and virtual, using contemporary and projected technology. The teacher can structure and influence the learning opportunities involved, even when not physically present.'

In fact, one has to look for other opportunities and online communication is a way that can increase the contact with the target language(s). Through these online encounters and their negotiations, one can develop the ability to overcome possible communication problems which normally occur during face-to-face conversation. Moreover, the informal nature of speech and its proximity to a conversational discourse make synchronous conversation a possible way of developing one's linguistic repertoire by contacting with genuine input.

By interacting with native speakers, chatters can gain awareness of cultural issues and the importance of being multilingual within today's world scenario, and moreover they are able to negotiate representations of their own and each other's culture by means of language and electronic discourse. In this way, this interactional context can help intercultural cybercommunicators build multiple language acquisition and communication skills.

Taking the concept of 'imaginary folklore' into consideration, which can be defined as students' perceptions (stereotypes, images, representations) about languages and speakers (cf. Richard \& Lockart, 1998: 54), one can also focus on one of the main features of cybercommunications: the dialogical construction and negotiation of representations of languages in the context of online multilingual synchronous conversation, i.e., chatters' interactional 'dialogical imaginary'.

'Dialogical imaginary' is related to another concept: representation. A representation is generated by individuals in a particular social (historical, political, economical, etc.) context (cf. Bonardi \& Roussiau, 1999: 18), in a dynamic social and dialogical process of construction and reconstruction (Matthey, 1997). Therefore, as social product, representations are not only from the social domain but also from the individual domain. Moreover, one can say that the redefinition and transformation of a representation clearly depends on the new communicative contexts, such as the one we are dealing with: multilingual cybercommunication. According to Py (2000: 6), 'dans la conversation il s'agit d'un sens social, négocié entre les interlocuteurs et référé par le langage à des schèmes qui existent dans la culture du groupe en tant que ressources collectives, par exemple sous la forme de formules stéréotypées, et qui sont théoriquement accessibles à tous les membres du groupe.' [During a conversation there is also the appearance of a social awareness, negotiated by the interlocutors and verbalised through language patterns which exist in the culture of the group as collective constructs. This is 
for example quite visible in the form of stereotypical formulas which are theoretically accessible to all group members.]

Shi-xu (2006) goes further in the analysis and argues that 'our thinking and feeling are discursive in nature because they are culturally constructed through, presumed in, mediated by, modeled upon, and born out of, discourse'. In fact, according to Gajo (2000), there are two types of representations: representation as a preconstruction and representation as a coconstruction. The former is implicit and stable and the latter is explicit and open to changes. As far as Serra (2000) is concerned, an articulation between these two types of representation results in ruptures in the discourse coherence because during the conversation one has contact with multiple voices, topics and cultural references, rebuilding one's own Weltwissen. In fact, these ruptures allow discourse participants to negotiate meaning with their interlocutors. In comparison with the foreign language classroom, we think that this kind of negotiation also occurs during online interaction but with its own limitations.

According to Vasseur (2001: 135), 'les représentations ne constituent pas des objets isoles et stables, mais qu'elles émergent, se manifestent et peuvent se transformer au cours des interactions dans des dialogues qui les révèlent. N'importe quel dialogue, n'importe quelle activité discursive, par exemple le récit (...), donne des indications sur la façon dont chacun des protagonistes se positionne par rapport à l'autre et par rapport à ce qu'il fait là avec l'autre, par rapport à l'activité en cours.' [Images are not isolated and stable objects. They emerge, can be seen and can be transformed during the interactions in which they are revealed. Any dialogue, any discursive activity, for example the story (...), provides guidance on how each of the protagonists is positioned in relation to each other, to what they are doing there with another, and to their role in the interaction.]

There is another concept related to the process of negotiation of representations: 'places discursives', i.e. the roles played by each participant, which are understood as the places (re)built within the interaction field and that are characterised by their dynamic, as the expression 'mouvement de places' suggests (François, 1990: 47). These concepts are the result of an expected role positioning in the discourse by the different conversation partners, respecting each one's interactional role (cf. Goffman, 1973). Speakers are able to identify and build their own place in the discourse, express their own opinion and talk about their own perception of the interaction.

We call this sort of activity 'dialogical dynamics', i.e., the complexity of movements and clashes which occur during a conversation and that are a result of the different roles and statuses of the different interlocutors (cf. Vasseur, 2000). These discursive movements are felt through different communicative behaviours: linguistic and paralinguistic forms; nonverbal communication (silences, gestures, smiles, frowning); reply nets which show dialogical places (question-response, question-question, etc.); and discourse organisation (if it is a narrative or an informative text). Moreover, we have to consider that there is also a positioning game in relation to: (1) the discourse object because the speaker can be more or less interested or even unhappy in the topic of conversation; (2) the activity that is happening, which can be desired or not, familiar or unfamiliar, known or unknown; (3) the discourse 
itself, which can be controlled by the different partners or not; and, finally, (4) the language and culture that is being used because it can be known or not (Auchlin, 1995).

This dialogical construction is created by the established clashes that occur during the conversation. These are the result of tensions between preconstructions and representations, which are born and built during the discourse itself, which is also related to Vasseur and Hudelot's (1998) 'dialogical imaginary', defined as the 'ensemble d'idées que chacun de nous se fait intuitivement quant au fonctionnement de son interlocuteur dans le dialogue qu'ils construisent ensemble' [set of ideas that each of us intuitively build upon our interlocutor in the dialogue which is a joint activity].

In this way, we can take the representations about the communicative situation as a whole into account, in which different speakers occupy different discursive places, play different roles and possess different multilingual repertoires.

\section{Online Mobility in Action: Negotiation of Representations of Languages}

\section{Corpus and methodology}

Our analysis is based on a corpus that entails two multilingual and intercultural chat sessions in the scope of a project, in which chatters from Portugal (university students learning English as a Foreign Language) and North America (university students learning Portuguese as a Foreign Language) interacted in several languages during two chat sessions (using either their native language or any other language).

The students from the University of Yale (USA) are attending a Portuguese as a Foreign Language course. Eight of these students are attending graduation courses in the fields of languages and economics. Three other students are attending postgraduation courses in the fields of international relations, history and management. Their ages range from 18 to 30 years old. Almost all of them are English native speakers but there are two members who are bilingual, having Spanish as their native language.

The Portuguese group is more homogeneous. These students are attending a graduation course in Social Education at the Escola Superior de Educação de Paula Frassinetti, in which they have a subject related to English language and culture. All of them have Portuguese as their native language and there is one bilingual student, who comes from Venezuela and therefore has Spanish as her first language and Portuguese as her second one.

The data were collected by recording the established chat sessions between the two groups. We used the WebCT platform to create a chatroom and logins and passwords for every student.

The agreed topics of the sessions were: first session - personal life of the chatters; second session - present-day issues, such as the problem of terrorism. The first session involved the discussion of the following topics: the choice of a franca language for intercultural communication; the importance of English language in the present-day society; the changes that 
languages are suffering; the daily life of chatters, etc. In relation to the second session, this one involved the organisation of Euro 2004 in Portugal, Rock in Rio Lisboa and the terrorism that occurred in New York and Madrid. All these topics were agreed by both teachers and were related to the programmes of the subjects they taught.

Our main aim was to put students in 'real' multilingual contact situations, in which we expected that the linguistic and cultural 'imaginary folklore' would materialise. We believe that interaction is the 'best place' to observe and to analyse the emergence and discursive negotiation of this kind of representation about languages and culture.

Because of the characteristics of chats - as a multiuser environment, full of textual overlaps, with an unpredictable topic change - we selected some segments of conversations, considered as more relevant and expressive. Then we reconstructed the conversational sequences in order to better comprehend the appearance and (re)construction of dialogical imaginary.

We have selected our conversational sequences in terms of discursive evidence of these dynamics, taking into consideration the specific features of online conversation. This resulted in three sequences of analysis. These were identified and selected with reference to the languages representations, which constitute the interactional topic.

In this way, at first, we started identifying complete sequences with the same meaning unit and then we named them in order to correctly identify their dominant topics during the analysis. Secondly, we focused on the exchanges that one can find in the negotiation of representations of languages, which occur inside these complete sequences.

Therefore, each of these three sequences presents a dominant interactional topic, which we have labelled as: (1) language as a cultural object; (2) language as a learning object; and (3) language as an affective object.

This sort of discursive positioning occurs in the dialogical activities, in which chatters make use of negotiation strategies (cf. Araújo e Sá \& Melo, 2003b; Vieira, 1988). In this study we have considered the following dialogical activities: confirmation, which occurs when chatters show they agree with the conversational topic or the representation shown in the discourse; reformulation, which takes place when chatters change their discourse in order to make themselves understood and show their representations of languages in a more comprehensible way; expansion, which is related to the addition of an idea to another idea, forming a more complete representation; requests for clarification, which are felt whenever there is a need to understand anything which is not completely clear; and, last but not least, the abandonment of the topic which takes place when chatters avoid the topic or subtopic of the conversation.

At the same time, during the negotiation process of languages representations, there are multiple resources available, which chatters strategically and creatively use. In this specific analysis, we focused on the keyboard resources and languages. In relation to the communicative situation resources, codeswitching occurs quite frequently (Poplack, 1980: 583), but there is also a strong use of smileys, capital letters, grapheme repetition, phonetic writing and interjections. This has to do with the variety of languages used and the management of the linguistic repertoires of the chatters, mainly the ICC and 
PC (cf. Oesch-Serra \& Py, 1993: 3). In our opinion, chatters change and switch languages for many reasons, namely:

- as support for comprehension, by using translation;

- as reduction of risks in the discursive construction, and at the same time to make interaction a lot easier;

- as expression of affectivity, taking into consideration the different roles and status of languages;

- as a means to express knowledge which is sometimes difficult to mention in another language;

- and, finally, as an affirmation of identity because one can express one's culture by using one's own language or languages.

\section{Languages as cultural objects}

In our corpus we find a lot of language and cultural representations, which is not surprising if we consider that they are inevitable when we are talking about intercultural encounters (cf. Amossy \& Pierrot, 1997: 43). On the one hand, one can get in touch with self-representations, i.e. representations that chatters have got of their own language, culture and people; on the other hand, one can also perceive representations of the other, their language and culture. Examples of self-representations can be seen in expressions such as:

Example 01: 'bete (Porto)-(bete)>>portugal é muito giro' [Portugal is very beautiful];

Example 02: 'palhaco (New-York)-(palhaco) >> our cities a dump'; Example 03: 'ana (New-York)-(ana) >> connecticut e um estado pequeno' [Connecticut is small state];

Example 04: 'mari (New-York)-(mari) >>Yo soy chicana' [I'm a Chicana];

Example 05: mari (New-York)-(mari) >> Una chicana es alguien que tiene interes en los problemas sociales, politicos, etc que afectan a la comunidad latina [A Chicana is someone who has interest in social, political problems which affect the latin community]. ${ }^{2}$

These self-representations are always related to a strong identity affirmation because they both feel proud of their cultural roots and they bring them up for discussion. At the same time they make the other feel curious about those cultural roots.

Therefore, when realising that they have the chance to contact with a true Chicana, many of the chatters of Portuguese origin, who have already talked about the Chicana issue during English Language classes, try to contact 'mari'. 'Mari' continues defining herself but at this time using the English language, which portrays this online discourse as a multilingual one:

mari (New-York)-(mari) $>>$ A chicana used to just be someone who had mexican parents, but was born in the US. After the Chicano movement, it became more of a political term; a chicano is someone who is involved in the Latino community and cares about political and social issues that affect the Latino community. 
One can find here a representation of three types: self-representation of her culture, self-representation of her people and an identity affirmation. Other cultural self-representations are related to the chatter's daily routines and traditions, such as:

Example 01: 'c_trem (New-York)-(c_trem) >> aqui nos estados unidos e muito comun sair da casa para ir a universidade' [here in the USA it is very common to get out of home to go to a university];

Example 02: 'tete (Porto)-(tete) $>>$ na vespera de natal comemos bacalhau cozido com todos.e no próprio dia de natal anho assado ou vitela estas são as tradicoes na minha aldeia joão' [at Christmas Eve we eat codfish with potatoes and at the Christmas Day roast beef these are traditions of my village João].

Curiosity towards other's customs and traditions can also be found, whenever chatters refer to their own culture and the other's culture though observations, such as:

Example 01: 'Garfield (Porto)-(Garfield) >> SOU FASCINADO PELA CULTURA CHICANA' [I'M FASCINATED BY THE CHICANA CULTURE];

Example 02: 'palhaco (New-York)-(palhaco) $>>$ we listened to fado the other day'.

Sometimes this curiosity is seen through the use of the imperative verbal form, showing the desire to listen to the other's voices, which is an important characteristic of the 'intercultural cybercommunicator' at the same time:

Example 01: 'castelodepaiva (Porto)-(castelodepaiva) $>>$ fala-me um pouco da california MARI' [Talk a little bit about California MARI];

Example 02: 'tschinhaALG (Porto)-(tschinhaALG) $>>$ fala-me de mexico C-TREM' [Speak about mexico C-TREM].

We are dealing with a conversational cycle which is ruled by one's curiosity towards the other's culture and people:

Example 01: 'beatriz (Porto)-(beatriz) >> when i went in NY i love the music in the discos';

Example 02: 'bebedomar (Porto)-(bebedomar) $>>$ os espanhois sao o povo que mais protege a lingua e falam sempre em espanhol' [Spanish people are one of the peoples that are most protective about their languages and talk always in Spanish];

Example 03: 'k (New-York)-(k) >> wakatanka, agora estou lindo livros de historia brasileira. A semana passada lei Casa grande e senzala [wakatanka, now I am reading books of Brazilian history. Last week I read Big House and Sanzala];

Example 04: 'c_trem (New-York)-(c_trem) $>>$ eu quero dizer que Portugal nao fez nada para ser ' a target of ewrrorism' e um pais muito bom' [Portugal did not do anything to be a target of terrorism ... It's a very good country]. 
From a specific topic one moves to another topic and from a representation one moves to another one. Moreover, this negotiation of representations is the result of communication clashes that occur due to their different linguistic and cultural repertoires. The result of this exchange is a redefinition of the representations of the languages, cultures and people, as we can see in the following examples:

Example 01: 'Joao (New-York)-(Joao) >> THE EURO IS THEN TELLING OF WHAT THE EC IS DOING WITH LANG. EMPHASIZING THE DIFFERENCES';

Example 02: 'wakatanka (Porto)-(wakatanka) >> latim was the franca language?i didn' know that'.

These examples are evidence of cultural relativism and redefinition of chatter's representations towards cultural diversity. Furthermore, they show us the desire to be evaluated by others in order to achieve a better understanding of one's own but also of the Other: 'Garfield (Porto)-(Garfield) $>>$ WHAT ABOUT OPORTO WINE ... , MARI?'. In fact, self- and group representations 'reveal how a group perceives its own identity, and demonstrate its cohesion. They provide a framework for interpretation, through comparisons and contrasts with characteristics attributed to other groups' (Castelloti \& Moore, 2002: 8).

\section{Languages as learning and affective objects}

Now we will try to focus our attention on some representations that occurred during our chat sessions, namely those related to languages and to the plurilingual communicative situation itself. First, it's easy to imagine that if this is a multilingual communicative situation, chatters will talk about languages, their own and others' linguistic repertoires:

Example 01: 'beatriz (Porto)-(beatriz) $>>$ falas muito bem português' [You speak very good Portuguese];

Example 02-'c_trem (New-York)-(c_trem) >> voce fala ingles muito bem' [You speak English very well];

Example 03: 'tete (Porto)-(tete) >> ainda bem que sabes português' [It's good that you know Portuguese];

Example 04-'didinha (Porto)-(didinha) >> ESCREVES MT BEM PORTUGUES' [You write Portuguese very well].

Sometimes we can also find evidence of language projects, like 'tschinhaALG (Porto)-(tschinhaALG) $>>\mathrm{k}$ eu tambem quero aprender italiano e tambem alemão' [I also want to learn Italian and German too].

In fact, we are talking about a conversational context ruled by one's curiosity towards other's language and repertoires.

Moreover, we can notice that languages are taken as objects one can observe in action. As told by Lüdi and Py (1986: 98), languages are social objects that can be discussed once 'elles se distinguent les unes des autres par des trais caracteristiques (musicalité, clarté, expressivité, difficultés d'apprentissage, utilité, etc.)' [they are distinguished from each other due to their characteristics 
(melody, clearness, expressiveness, learning difficulties, usage, etc)]. For this reason, we can observe, compare and establish hierarchies of languages in several aspects, namely:

1. importance: 'tschinhaALG (Porto)-(tschinhaALG) $>>0$ frances é tão importante como o ingles portugues ou italiano'. [French is as important as English, Portuguese or Italian];

2. difficulties

- related to language learning: 'alam (Porto)-(alam) $>>$ iglês é facil de aprender' [English is easy to learn], 'bete (Porto)-(bete) $>>$ eu nao tenho muitas bases, antes prefiro o frances ou espanhol percebe-se melhor. ANA' [I don't have a lot of knowledge about it but I prefer French or Spanish they are easier to understand];

- related to language use: 'teca (Porto)-(teca) $>>$ ainda bem que falas português e ... muito bem! Também acho que o inglês é dificil mas ... é a nossa lingua unoversal certo?' [it's very good that you speak Portuguese and great indeed! I also think that English is difficult ... but it is our universal language, isn't it?]; 'wakatanka (Porto)-(wakatanka) $>>$ chines!!!!???it' so difficult K!'; 'sunlight (Porto)-(sunlight) $>>$ yes, $\mathrm{i}$ think to, chines is very difficult, $\mathrm{K}^{\prime}$;

3. similarities and differences: 'alam (Porto)-(alam) $>>$ espanhol é parecido com o português, por isso português também é facil' [Spanish does look like Portuguese, but Portuguese is also easy];

4. aesthetic preferences: 'palhaco (New-York)-(palhaco) $>>0$ portugues eh o mais lindo kkkkk' [Portuguese is the most beautiful one kkkkk]; 'alam (Porto)-(alam) >> muito bem, nós também gostamos muito de português' [Very good, we also like Portuguese a lot]; 'palhaco (New -York)-(palhaco) $>>$ english is ugly'; 'smile (Porto)-(smile) $>>$ eu adoro inglês [I love English]'

5. linguistic particularities: 'sunlight (Porto)-(sunlight) $>>$ teça e raquel, i think portuguese language is very difficult to be universal because have to many 'sintaxes', its not a simple language'.

6. Self representations: related to chatter's native language and cultural identity are also abundant. We can notice them in the use of the possessive pronoun (My, NOSSA): 'bete (Porto)-(bete) >> no ... My POtugese Para sempre' [My Portuguese forever]; 'bebedomar (Porto)-(bebedomar) $>>$ AQUI EM PORTUGAL A NOSSA SEGUNDA LINGUA É O MIRANDES' [Here in Portugal our second language is Mirandese].

As we can observe, these processes of comparison, analysis and evaluation are ruled by personal opinions which are often anchored in personal and social representations and stereotypes, about one's own and each other's languages. These representations, as social constructions, are used in the interaction and they become discursive topics, able to be changed or reconstructed.

When talking about the present-day lingua franca, English, one of the American chatters refers to it as being one of the ugliest languages and that English should not play the role of a lingua franca because it is so ugly; afterwards he asks the opinion of the other chatters. Some of them agree, such 
as 'caty(Porto) - (caty) >> concordo contigo k' [I agree with you k]; smile (Porto) - (smile) >> Claro que concordo!' [Of course I agree!], being asked by palhaco to change the language of conversation. Coalitions are inevitably formed between chatters who agree with palhaco and the ones who do not agree, requiring a clearer explanation: 'ana (New York) - (ana) >> Por que acham que o ingles e feio?' [Why do you think English is ugly?]. The chatter called palhaco argues that English sounds ugly.

In fact, as stated by Amossi and Herschberg Pierrot (1997: 37), 'dans la société contemporaine, les constructions imaginaires dont l'adéquation au réel est douteuse sinon inexistante sont favorisées par les médias, la presse et la littérature de masse. Souvent le public se forge par la télévision ou la publicité une idée d'un groupe national avec lequel il n'a aucun contact.' [At the present society, imaginary constructions of the reality (if they do not really exist) are promoted by the media, the press and mass literature. Often the public is forced to focus on an idea of a national group with which it has no contact at all.] We think that this assumption is also worthy of language representations because, as we have said before, languages, as objects, are observable and they can become discursive topics, negotiated, modified, abandoned or replaced by others during the interaction.

Focusing now on the barriers to multilingual interaction, we can find some negative representations about some of the languages ('c_trem (NewYork)-(c_trem) >> nao, ja disse que odio português' [no, I have already said that I hate Portuguese]), which can be a result of chatters' aesthetic preferences or of chatters' negative representations about their language skills ('c_trem (New-York)-(c_trem) $>>$ por que e tao difícil (...) c_trem (NewYork)-(c_trem) $>>$ eu saco malas notas' [Because it is very difficult... I have bad marks]).

To sum up, we can say that in a multilingual chat interaction representations about languages and cultures are quite frequent because they are the vehicle to achieve communication. It is also common to find chatters' observations about the communicative support and its possibilities in terms of space and time ('wakatanka (Porto)-(wakatanka) >> seatle, que fixe!sabes é porreiro estar a falar contigo, estas tao distante ...' [seatle, great! It is cool to talk to you, you are so far away ... ]) and its advantages when it comes to linguistic evolution ('schmoopy (New-York)-(schmoopy) $>>$ I think that 'chatting' and Internet usage is going to change English more than the fact that people all over the world speak it as their second language'), showing how aware they are of the transformations imposed by the use of technology.

Taking this observation into account, we can conclude that this communication tool is changing 'linguistic folklore' and helping to redefine roles and representations of languages in society, namely in Internet communicative contexts. However, the ultimate goals are communication and the achievement of cross-cultural understanding.

\section{Conclusion}

In the last few years a new form of mobility has emerged: online mobility. This can be defined as the possibility to travel through the virtual world of the 
Internet and of its communication spaces, breaking barriers imposed by the lack of knowledge of its codes and languages. Therefore, it is important to think about the use of online communication (especially synchronous) in the development of the ICC and PC of worldwide chatters.

In this study, we focused on the development of some of these competences and analysed the negotiations of representations of languages and cultures in cybercommunication. We identified the ways in which these images, as signs of affective and communicative predispositions (as they are mostly positive), help chatters to become engaged in the interaction, to solve communicative problems and to coconstruct multilingual intercomprehension (cf. Melo, 2006). We were able to see that the 'dialogical imaginary' is particularly important in the analysis of discursive representations and that conversational clashes occur and are the reason for the reconstruction of representations. In fact, chatters show their self- and group representations of languages and cultures which become a negotiation object in a discursive game. This discursive game involves various processes, namely: identity construction, identity affirmation, particular selection of some interlocutors and social and affective reactions towards languages, cultures and communicative situation itself.

Generally speaking, one can say that chatters tend to love their own native languages. Apart from the fact that there is also a great curiosity about the traditions and customs of the Other, chatters like to negotiate those representational and discursive tensions inevitably tend to occur. These negotiation processes oscillate between the concordance and the discordance spheres. This can be felt in the constant requests for clarification which are quickly answered by chatters. There is also a strong code shifting, in which the preference for some languages can also be seen.

In the reconstruction of identities, reassuring of identities, selection of a specific interlocutor, etc. there is a discursive struggle for power in the discourse. To achieve this, chatters form coalitions and struggle so that their own opinions about the topics are really heard and valued.

In this way, we were able to observe the ICC and PC domains in action by true intercultural cybercommunicators. Taking all this into account, one can now define the profile of a perfect 'intercultural cybercommunicator' as one:

- who is a member/carrier of the diversity and multilingualism that circulate in the cyberspace;

- who is capable of travelling in the virtual world by using software, hardware, communication tools, language codes;

- who is able to develop one's ICC, negotiating knowledge with the Other;

- who can surpass communicative problems which may occur in intercultural cybercommunication, making use of one's own multilingual repertoires;

- who can bring cultural topics up in intercultural cyberdiscourse in order to develop one's cultural awareness of the world.

\section{Acknowledgements}

Financial support was received from Fundação para a Ciência e a Tecnologia, Ministério da Ciência, Tecnologia e Ensino Superior (Portugal). 


\section{Correspondence}

Any correspondence should be directed to Mário Rui Domingues Ferreira da Cruz, Avenida Fernando Augusto Oliveira, Sector-6, lote-8, 3800-540 Cacia, Portugal (mariocruz@live.com).

\section{Notes}

1. For more information please check the following website: http://www.eujapan. com/EUROPE/vulcanus_japan.html.

2. Examples were not edited in any way.

\section{References}

Amossy, R. and Herscheberg Pierrot, A. (1997) Stéréotypes et clichés. Paris: Nathan Université Ed.

Araújo e Sá, M.H. and Melo, S. (2003a) Del caos a la creatividad: los chats entre lingüístas y didactas. In C. Alonso and A. Séré (eds) Los textos electrónico: nuevos géneros discursivos (pp. 45-61). Madrid: Biblioteca Nueva.

Araújo e Sá, M.H. and Melo, S. (2003b) ‘Beso em português diz-se beijo:*': la gestion des problèmes de l'interaction dans des chats plurilingues romanophones. In C. Degache (ed.) Intercompréhension en langues romanes. Du développement des compétences de compréhension aux interactions plurilingues, de Galatea à Galanet, Lidil 28 (pp. 95-108). Grenoble: ELLUG.

Auchlin, A. (1995) Le bonheur conversationnel: émotion et cognition dans le discours et l'analyse du discours. In D. Véronique and R. Vion (eds) Modèles de l'interaction verbale (pp. 224-233). Aix-en-Provence: Publications de l'Université de Provence.

Bonardi, C. and Roussiau, N. (1999) Les représentations sociales. Dunod: Les Topos.

Byram, M. (1997) Teaching and Assessing Intercultural Communicative Competence. Clevedon: Multilingual Matters.

Byram, M. (2000) Pluralism, Identity, and a Guide for Language Education Policy. Conference papers 'Europäische Sprachenpolitik'. Würzburg, 6-8 July.

Castelloti, V. and Moore, D. (2002) Social Representations of Languages and Teaching: Reference Study for the Guide for the Development of Language Education Policies in Europe: From Linguistic Diversity to Plurilingual Education. Strasbourg: Council of Europe.

Council of Europe (2003) Guide for the Development of Language Education Policies in Europe: From Linguistic Diversity to Plurilingual Education. Executive version.

Cruz, M. (2005) Cibercomunicador Intercultural: imagens das línguas em chat plurilingue. Dissertação de Mestrado. Aveiro: Universidade de Aveiro.

Cruz, M. and Melo, S. (2004) Mobilidade on-line: potencialidades da comunicação plurilingue em chat. Saber Educar, 9. Porto: ESE de Paula Frassinetti, pp. 99-114.

Draelants, H. (2001) Le "chat": un vecteur de lien social? Esprit critique 3 (10). On WWW at www.espritcritique.org.

François, F. (1990) La communication inégale. Genève: Delachaux et Niestlé.

Gajo, L. (2000) Disponibilité sociale des représentations: approche lingustique. Tranel, 32, Université de Neuchâtel, pp. 39-53.

Goffman, E. (1973) La mise en scéne de la vie quotidienne. 1. La présentation de soi. Paris: Minuit.

Matthey, M. (1997) Représentations sociales et langage. In M. Matthey (ed.) Les langues et leurs images. Neuchâtel: IRDP Editeur.

Melo, S. (2006) Emergência e negociação de imagens das línguas em encontros Interculturais plurilingues em chat. Tese de Doutoramento. Universidade de Aveiro, Aveiro (Documento policopiado).

Morala, J. (2001) "Entre arrobas, eñes y emoticons". Apresentação no "II Congresso da Língua Espanhola, Valladolid". October 2001. On WWW at http:/ / distritos.telepolis. com/internautas/lib/Documentos/emoticones.doc 
Oesch-Serra, C. and Py, B. (1993) Dynamique des représentations dans des situations de migration. Étude de quelques stereotypes. In G. Lüdi, Bulletin Cila 57. Neuchâtel: Université de Neuchâtel, pp. 71-83.

Poplack, S. (1980) Sometimes I'll start a sentence in English y termino en español. In L. Wei (ed.) The Bilingualism Reader (pp. 221-256). London/New York: Routledge.

Portine, H. (2001) Chat sans socialisation-rationalisation n'amasse pas mousse. In R. Bouchard and F. Mangenot (eds) Interactivité, interactions et multimédia, Notions en Questions, 5 (pp. 169-188). Lyon: ENS Editions.

Py, B. (2000) Représentations sociales et discours. Questions épistèmologiques et méthodologiques. Tranel 32, 5-20.

Richards, J. and Lockhart, C. (1998) Estrategias de reflexión sobre la enseñanza de idiomas. Cambridge: Cambridge University Press (trad.).

Serra, C. (2000) Traitement discursif et conversationnel dês représentations sociales. Tranel 32, 77-90.

Shi-xu (2006) Mind, self, and consciousness as discourse. New Ideas in Psychology 24 (1), $63-81$.

Shi-xu and Wilson, J. (2001) Will and power: Towards radical intercultural communication and research and pedagogy. Language and Intercultural Communication 1 (1), 76-93.

Tella, S. (1995) Virtual school in a networking learning environment. In OLE Publications, 1, Department of Teacher Education. Helsinki: University of Helsinki. On WWW at http://www.helsinki.fi/ tella/ole1.html. Accessed 18.3.03.

The New London Group (2000) A pedagogy of multiliteracies designing social futures. In B. Cope and M. Kalantzis (eds) Multiliteracies: Literacy Learning and the Design of Social Futures (pp. 9-37). London: Routledge.

Vasseur, M.-T. and Hudelot, C. (1998) Imaginaires et pratiques didactiques dans les dialogues experts-novice. In C. Springer (ed.) Les linguistiques Appliquées et les Sciences du Langage (pp. 100-112). Université de Strasbourg.

Vasseur, M.-T. (2000) Du bom usage de l'inégalité dans l'interaction interlingue. AILE, 12, Publication Encrages, Université de Paris, 8, 51-76.

Vasseur, M.-T. (2001) Places discursives, imaginaire dialogique et apprentissage de la langue. In D. Moore (ed.) Les représentations des langues et de leur apprentissage: références, modèles, données et méthodes. Paris: Didier.

Vieira, I. (1988) Interacção verbal e negociação do saber na aula de língua estrangeira. Tese de Mestrado, Universidade de Aveiro, Aveiro.

Warschauer, M. (1999) Electronic Literacies: Language, Culture, and Power in On-line Education. Mahwah, NJ: Lawrence Erlbaum Associates.

Mário Rui Domingues Ferreira da Cruz (mariocruz@live.com) is a lecturer at Escola Superior de Educação de Paula Frassinetti and an investigator at Universidade de Aveiro. He is the Coordinator of the Postgraduation Course in Early English Teaching and he teaches Didactics of English Language, Educative Technologies applied to English Teaching and Intervention in the Early English Teaching. He supervises the work of future Primary School teachers. He has also participated in two renowned investigation projects: InterProject, a Comenius project which involved the promotion of Intercultural approaches at schools and won the Evens Prize; Representations of Languages in Intercultural Communication, a Portuguese project for the promotion of Intercultural Communicative and Plurilingual Competences in schools. At this moment he is a PhD student in the field of Didactics and Educative Technology at Universidade de Aveiro, under the supervision of Professor Maria Helena Araújo e Sá and Professor António Moreira. 